Article

\title{
Perceptions of Social Responsibility for Community Resilience to Flooding: A Comparison between Communities in Indonesia and the UK
}

\author{
Robby Soetanto ${ }^{1, *(\mathbb{D}}$, Ferry Hermawan ${ }^{2}$, Nafsika Drosou ${ }^{1}$, , Lee Bosher ${ }^{1}\left(\mathbb{C}\right.$ and Jati Utomo Dwi Hatmoko ${ }^{2}(\mathbb{C})$ \\ 1 School of Architecture, Building and Civil Engineering, Loughborough University, \\ Leicestershire LE11 3TU, UK; n.c.drosou@lboro.ac.uk (N.D.); 1.bosher@lboro.ac.uk (L.B.) \\ 2 Department of Civil Engineering, Diponegoro University, Semarang 50275, Indonesia; \\ ferry.hermawan@live.undip.ac.id (F.H.); jati.hatmoko@ft.undip.ac.id (J.U.D.H.) \\ * Correspondence: r.soetanto@lboro.ac.uk; Tel.: +44-1509-228-748
}

Citation: Soetanto, R.; Hermawan, F.; Drosou, N.; Bosher, L.; Hatmoko, J.U.D. Perceptions of Social Responsibility for Community Resilience to Flooding: A Comparison between Communities in Indonesia and the UK. Water 2022, 14, 433. https://doi.org/10.3390/w14030433

Academic Editor: Maria Mimikou

Received: 27 December 2021

Accepted: 25 January 2022

Published: 31 January 2022

Publisher's Note: MDPI stays neutral with regard to jurisdictional claims in published maps and institutional affiliations.

Copyright: (C) 2022 by the authors. Licensee MDPI, Basel, Switzerland. This article is an open access article distributed under the terms and conditions of the Creative Commons Attribution (CC BY) license (https:// creativecommons.org/licenses/by/ $4.0 /)$.

\begin{abstract}
Over the last few decades, flood hazards have had a greater impact on society, meaning that communities increasingly need to work together to enhance their resilience. Literature suggests that preparedness to flooding events is generally low as most individuals do not take protective actions. Therefore, there is a need to stimulate individuals' actions that increase their own and their communities' resilience to flooding. Various factors must be addressed to encourage individuals to take action, such as providing information to improve risk perception, understanding cognitive processes that interpret environmental stimuli against the mental model, and considering social and cultural influences. This paper argues that Social Responsibility (SR), defined as an individual willingness to take up actions that benefit society, is part of a pre-existing mental model that can explain intentions to take preparedness actions that improve community resilience. Due to differing socio-cultural contexts, the SR perceptions of communities in different parts of the world may differ. In order to investigate this phenomenon, data of SR perceptions obtained from 180 completed questionnaires were collected from flooded and non-flooded communities in Semarang, Indonesia, and then compared against those obtained from 313 questionnaires based on a survey of communities in Birmingham and London in the UK. The results suggest that Indonesian communities demonstrate a higher level of SR scores than UK communities. A comparison of SR scores between flooded and non-flooded communities in the UK shows a higher level of SR in flooded communities. In contrast, the comparison between corresponding Indonesian communities indicates an almost similar level of SR. A comparison of SR scores between Indonesian and UK flooded communities shows a higher level of SR in Indonesian communities across several measures. Further comparison of SR scores between Indonesia and UK non-flooded communities demonstrates higher SR in Indonesian communities in all but one measure. This suggests that experience of flooding has a much stronger influence on raising SR perceptions in UK communities. Socio-cultural background may explain these differences in SR perceptions, particularly, in relation to collectivism orientation and the close-knit nature of Indonesian communities. Although higher SR perceptions do not necessarily mean higher levels of preparedness actions, this finding illuminates the important influence of socio-cultural context on community resilience enhancing efforts that rely on collective actions by individuals.
\end{abstract}

Keywords: community; resilience; flooding; perceptions; social responsibility

\section{Introduction}

Climate change is regarded as the most critical global challenge faced by humanity and a key factor that increases the risk of flooding. Flooding has often left a devastating impact on communities in both physical and psychological ways and in short and longer terms. In some communities, flooding has caused damages with recovery periods that span years until a return to pre-flood conditions is achieved. In the last two decades, literature 
(e.g., [1]) recognises that community resilience may hold the key to improved preparedness, to minimal flooding impact, and to quicker recovery periods. Community resilience to flooding may be influenced by various factors, such as flood defence [2], adaptation and mitigation methods [3], flood warning systems [4], and insurance protection $[5,6]$. Nevertheless, enhancing community resilience is a combined effort between 'bottom-up' participation and 'top-down' policy implementation and, thus, requires collaboration between a range of relevant stakeholders. Whilst this need is well acknowledged, the responsibility for improving resilience is less clear [7], debatable, and often leads floodprone communities to rely solely on their own often limited resources.

Given the widespread risks and potential impacts on large geographical areas, to increase collective resilience, communities need to work together to mitigate risk and develop adaptation strategies that optimise the available shared resources. Individuals have important roles in this effort and could contribute to the community through actions that enhance collective resilience [1]. Despite the importance of resilience to flooding, preparedness to flooding (and other natural hazards) is generally observed to be low as individuals have not taken protective actions [8-12]. Individuals often deny their responsibility, thinking that someone other than them (often the government) is supposed to take responsibility [13]. This may be particularly prevalent to those with a perceived low risk of flooding (i.e., non-flooded communities), even though their actions could contribute to the increase in risk for other community members through either their inaction or actions that exacerbate flood risk (e.g., rubbish disposal practices).

In this paper, Social Responsibility (SR) is briefly defined as an individual's broader responsibility and willingness to contribute to collective actions to enhance the resilience of a community they are part of (developed based on [14]). This paper argues that SR may be part of pre-existing mental models that can explain intention to take preparedness actions that improve the resilience of the community where they live. Concepts related to personal responsibility including SR, responsibility for preparing/dealing with hazards, and responsibility for others have been identified as important factors that can influence preparedness to natural hazards $[12,13]$. One unique contribution of SR is that the concept indicates how individuals exercise their roles and their willingness to take initiatives, or be part of resilience-enhancing collective actions within the community. With the exception of Mullins and Soetanto [15] and Soetanto et al. [16], who investigated the perceptions of SR in relation to flooding for householders and local businesses in the UK, there is no other similar research that investigates the perceptions of SR of communities in contrasting socio-cultural contexts.

This paper reports on findings of an investigation to compare the perceptions of SR in flooded and non-flooded communities in Semarang (Indonesia) and Birmingham and London (UK). Communities in Semarang and Birmingham/London represent communities from two countries with different socio-cultural contexts. A comparison of perceived SR between communities in this manner will reveal the influence of socio-cultural factors. Further comparison of perceived SR between flooded and non-flooded communities allows an assessment of the influence of flooding experience on the level of SR. The following section describes the factors influencing preparedness to natural hazards with particular emphasis on the role of culture. Key literature on cultural differences between UK and Indonesia is presented, before the case studies in Semarang and Birmingham/London are described. Research methods including research approach, data collection in communities, SR measures utilised in the research, and data analysis are explained. Results, discussions, and conclusions follow, before practical and policy implications, and recommendations for further work are discussed.

\section{Factors Influencing Individual Preparedness Behaviour}

Previous research has identified a diverse set of factors that influence an individual's preparedness for natural hazards. Individual intention to take protective/preparedness actions that improve their own and community resilience is determined by cognitive pro- 
cesses that integrate the interpretation of environmental stimuli with pre-existing mental models ([17] cited from [18]). This process of interpretation is influenced by a myriad of factors. Risk perception is regarded as one of the important factors; however, it cannot fully explain individual intention to take protective actions. Other factors, such as protective action perceptions (or coping appraisal), hazard severity and probability, and negative emotions with predicted damage, were found to be predictors of protective behaviour [19-21]. Furthermore, Paton et al. $[18,22]$ argued that the level of preparedness for natural hazards can be predicted by individual outcome expectancy, community participation, and collective efficacy, as well as societal empowerment and trust. Due to the interpretive cognitive process of individual hazard preparedness, it is suggested that an understanding of preparedness actions could be advanced by investigating the personal, social, and cultural influences on how individuals interpret risk and preparedness issues [18,23]. However, social and cultural influences on the preparedness process are less well studied [13].

Paton et al. [22] investigated hazard preparedness in Japan and New Zealand, which have distinct cultural backgrounds. They argued that social and psychological factors that underpin beliefs and actions differ substantially across cultures. In individualistic cultures, individual behaviours are predominantly influenced by a motivation to achieve personal goals. Thus, collaboration and cooperation between individuals for collective action is a matter of personal choice rather than a cultural predisposition. On the other hand, in collectivistic cultures, individual behaviours are very much underpinned by culturally embedded beliefs that reflect in shared activities to achieve collective goals. Their findings suggest a more direct role that communities in Japan have in dealing with local problems, reflecting the closer relationship between community and neighbourhood in Japan (i.e. the community is locational). In contrast, New Zealand's community is predominantly relational, reflecting an individual's involvement in activities of common social interest rather than neighbourhood interaction. Thus, in relational communities within individualistic cultures, local hazard issues have to be explicitly raised in the decision-making process, instead of occurring as a natural consequence of community deliberations within collectivistic cultures [22]. A summary of personal, family, community, societal, environmental, and informational influences on preparedness is presented in [12], highlighting the need to include cross-cultural consideration to facilitate the application of preparedness theories in an international and multi-cultural context. Paton et al. [23] raised the question on the applicability of preparedness theories in different cultural settings because they were often developed and tested in Western countries with predominantly individualistic cultures. A greater understanding of preparedness could be achieved by investigating personal and socio-cultural influences on an individual's interpretation of risk and preparedness issues.

Previous research on natural hazard response and preparedness in Indonesia highlights the important role of social, cultural, and economic factors. For example, Lavigne et al. [24] identified attachment to place, cultural beliefs, and socio-economic constraints, apart from risk perception, as elements that shaped behavioural response to volcanic threats. Hellman [25] raised the issue of community embeddedness in local socio-economic networks, and the need to strengthen social and economic security systems before initiating a flood mitigation programme. In a study of the social effects on flood responses from children living in Surakarta, Indonesia, Taylor and Peace [26] identified four important cultural elements, namely the traditional practice of 'gotong royong' (in Javanese, or 'mutual help'), the role of local leadership at village and neighbourhood levels, the influence of religion, and the social position of children in the Indo-Javanese culture. 'Gotong royong' and local leadership encourage strong social cohesion, and promote greater reliance on community self-efficacy. Religious practices can motivate individuals to help others, and arguably enhance psychological coping and recovery in the aftermath of a disaster [26]. These traditional cultural elements together determine how communities perceive risks and respond to flooding, as they influence individuals from a very young age due to their participation in disaster response. Thus, it is likely to influence their perceptions of SR. 
Although the responsibility-related concepts (personal responsibility, responsibility for preparing/dealing with hazards, responsibility for others, and SR) have been identified as important factors that can influence preparedness to natural hazards [12,13], their specific impact on preparedness across different cultures has not been ascertained. Instead of investigating the direct influence of responsibility on preparedness action, this research adopted SR as one of the antecedents influencing individuals' willingness to undertake resilient behaviours that can significantly contribute to community resilience through individual and collective actions [16]. SR is an indicative measure of individual sense of being part of the community and their propensity to take actions that benefit that community. Soetanto et al. [16] investigated perceptions of SR in relation to flooding for householders and local businesses and established their relationships with experience of flooding and demographic factors of age, gender, and ethnicity. They found that older individuals from South Asian ethnic groups with previous flooding experience are likely to be more socially responsible than others without these attributes. Mullins and Soetanto [15] called for an in-depth investigation on the influence of 'ethnicity' on SR perceptions in different countries with different underlying cultural backgrounds (e.g., norms, beliefs, and values). Experience of flooding was found to be a strong predictor for preparedness (e.g., [27]), and the most important variable in predicting SR score in [16]. As flooding is a global challenge faced by communities in different socio-cultural contexts, it is vital to investigate the applicability of this finding and the extension of this SR concept across different communities with different perceptions of risk, behavioural norms, belief, and cultural background. The main research question that the paper addresses is 'are there differences in SR perceptions between flooded and non-flooded communities within each as well as across Indonesia and the UK?'

\section{Cultural Differences between Indonesia and the UK}

In their seminal work on national culture, Hofstede et al. [28,29] distinguished culture of different countries across six dimensions, namely Power Distance (PD), Individualism (IDV), Masculinity (MAS), Uncertainty Avoidance (UAI), Long-Term Orientation (LTO), and Indulgence (IVR). These dimensions can explain different beliefs and behaviours exhibited by individuals from different nations. These have been applied widely in diverse areas, including corporate management, consumer behaviour and marketing [30], team dynamics [31], environmental behaviour [32], and community participation in co-design for development in Indonesia and the UK [33]. Paton et al. [22] indicated three important cultural dimensions of Power Distance (PD), Individualism (IDV), and Uncertainty Avoidance (UAI) in comparing earthquake preparedness between communities in Japan and New Zealand. However, Paton et al. [23] further argued that Individualism (IDV) is the dimension with the greatest influence on preparedness theories.

The IDV dimension is seen to be most associated with the perception of SR. This dimension is argued to shape how individuals relate to others within their community, see their role within it, and propagate collective action. In a social network context, Hu et al. [34] proposed two drivers of collective action in individualistic and collective societies, namely individual motivation and social connectivity. In individualistic societies, collective action is more effectively widespread when people have a strong motivation to participate, and the connectivity of the social system is low. In contrast, within collectivistic societies, the spread of collective action is more effective when motivation is not strong, and the connectivity of the social system is high. The desire to emphasise group rather than individual interests in collectivistic societies can explain the less important role of individual motivation in comparison to social connectivity for participating in collective action. However, it is suggested that reliance on social connectivity in collective societies may compromise individual participation when weak ties that increase isolation exist within sub-groups. Thus, collectivism may not be favourable to the spread of participation across the entire network [34]. 
As suggested by IDV scores in Figure 1, the Indonesian society has a much lower score (14) than the UK society (89) [35]. Individuals from societies with high individualism (IDV) score such as the UK demonstrate 'a preference for a loosely-knit social framework in which individuals are expected to take care of only themselves and their immediate families' [35], whereas those from societies with low IDV score such as Indonesia show 'a preference for a tightly-knit framework in society in which individuals can expect their relatives or members of a particular ingroup to look after them in exchange for unquestioning loyalty' [35]. Indonesians tend to prioritise group interest, to conform to collective expectations, and to place high value on family cohesion, cooperation, solidarity, and conformity to social norms ([36] cited from [33]).

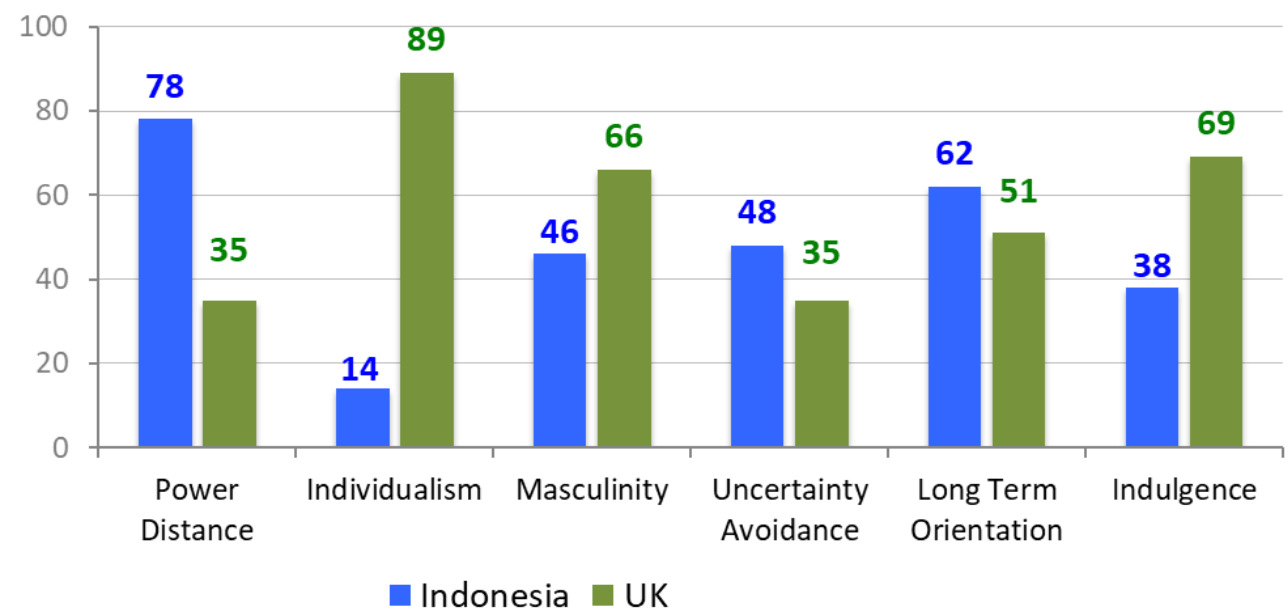

Figure 1. Comparison of Indonesia and UK culture across 6 dimensions (recreated from [35] in 2021).

\section{Case Study Areas}

The City of Semarang (see Figure 2 for location in Indonesia) is the capital of Central Java Province and the fifth largest city in Indonesia with a population of circa $1.6 \mathrm{~m} \mathrm{[37].}$ Semarang has a varied topography with lowland coastal area in the North, called 'Semarang Bawah' or Lower Semarang (where Old City is located), and hilly area in the South, called 'Semarang Atas' or Upper Semarang [37]. Historically, Semarang is prone to coastal and fluvial flooding [38]. Figure 3 depicts the occurrence of floods in Semarang between 2012 and 2018. On average, flooding occurred more than 25 times a year in different areas of Semarang [39]. In 2021, the worst affected areas experienced floodwater depth of between

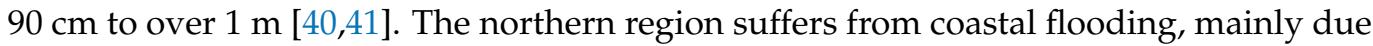
to excessive land subsidence, between 4 and $15 \mathrm{~cm}$ per annum [42] caused by rampant abstraction of groundwater. Some areas in the South often experience fluvial flooding from the main river, called 'Kaligarang'. Occasionally, surface flooding is due to poor drainage systems in both Northern and Southern regions. Due to the problem of persistent flooding, over time, there has been a population retreat to hilly areas in the South, leaving the Northern region to typically less affluent households.

Three communities in Semarang (Trimulyo, Karangayu, and Gunung Pati) were included in this study. Figure 2 shows the location of these communities. Both Trimulyo and Karangayu areas have high risks of coastal and fluvial flooding, respectively, whereas Gunung Pati has low risks of flooding. The demographic and social profiles of these three communities are provided in Table 1 [43]. 


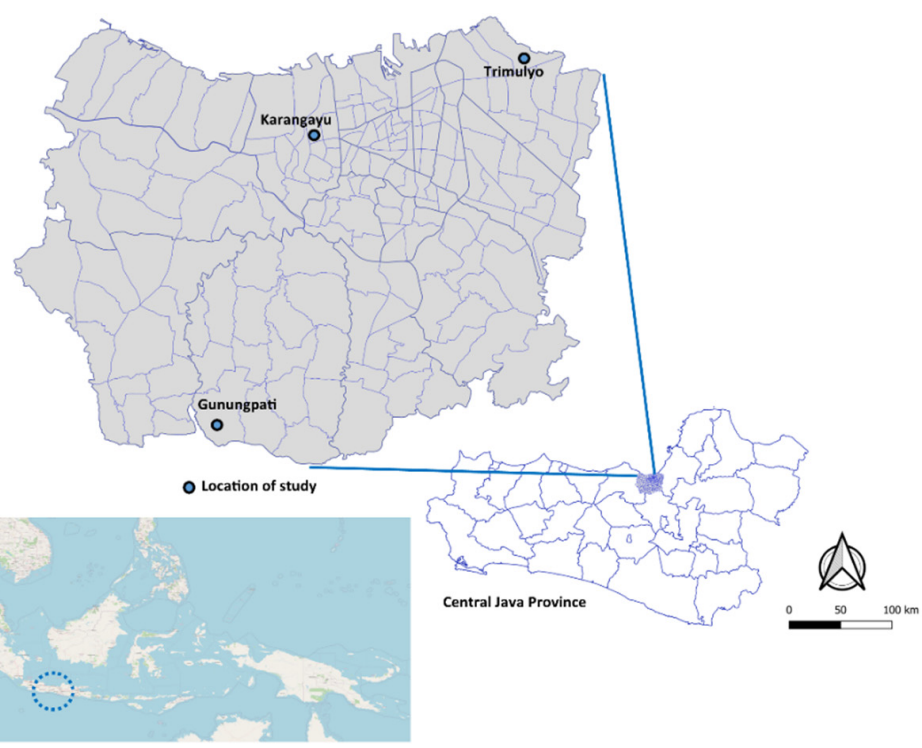

Figure 2. Location of Semarang (top) in Indonesia (bottom left), Central Java (right), and Semarang case study areas (3 dots in top image): Trimulyo, Karangayu, and Gunung Pati (recreated from [44]).

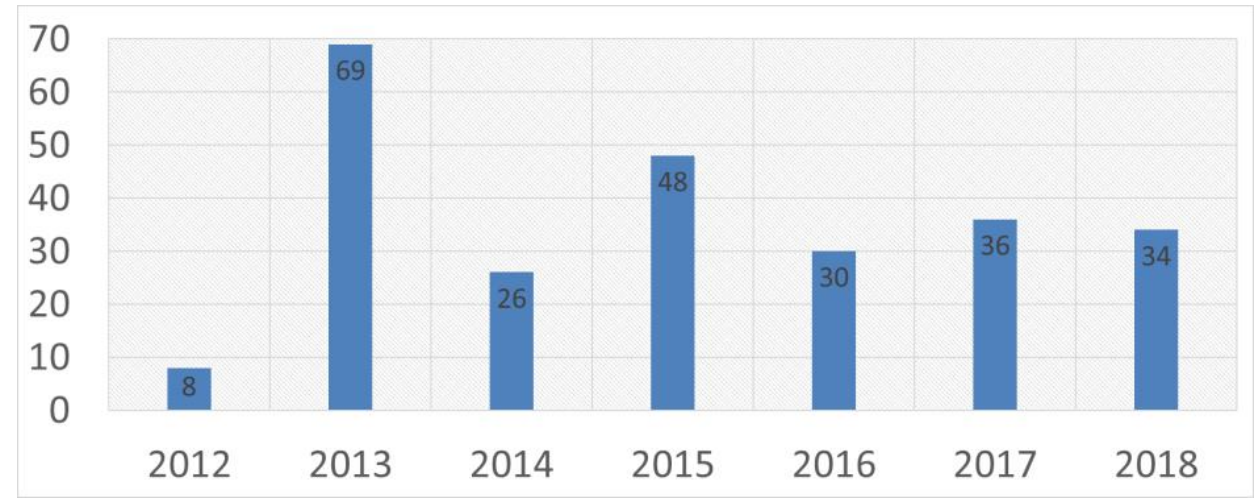

Figure 3. Flood occurrence in Semarang from 2012 to 2018 [39].

Table 1. Demography and social profile of three case study areas based on Semarang's Central Bureau of Statistics [45] (taken from [43]).

\begin{tabular}{|c|c|c|c|}
\hline & \multicolumn{3}{|c|}{ Case Study Areas } \\
\hline & Karangayu & Trimulyo & Gunung Pati \\
\hline \multirow{3}{*}{ Case study description } & North & North East & South \\
\hline & Between 2 rivers & Coastal & Elevated \\
\hline & Residential & Industrial & Residential \\
\hline Area $\left(\mathrm{km}^{2}\right)$ & 0.66 & 3.18 & 4.05 \\
\hline Population (in 2017) & 8780 & 3415 & 6522 \\
\hline Population density $\left(\mathrm{km}^{2}\right)$ & 7247 & 3633 & 1478 \\
\hline Population trend & Down (in 2017) & Down (in 2017) & Up \\
\hline Male/Female ratio & 0.997 & 1.043 & 0.979 \\
\hline Professions & $\begin{array}{l}29 \% \text { ind. workers; } \\
26 \% \text { entrepreneurs; } \\
21 \% \text { traders }\end{array}$ & $\begin{array}{c}72 \% \text { industrial } \\
\text { workers }\end{array}$ & $\begin{array}{l}51 \% \text { farmers } \\
13 \% \text { armed forces } \\
\text { civil servants }\end{array}$ \\
\hline Without a degree & $26 \%$ & $24 \%$ & $28 \%$ \\
\hline High school & $42 \%$ & $44 \%$ & $37 \%$ \\
\hline Higher education degree & $8 \%$ & $8 \%$ & $7 \%$ \\
\hline
\end{tabular}


Data obtained from these communities were compared with those from four communities in Birmingham and London in the UK, which were adopted from a previous study [16]. These communities were located in Witton, Selly Park, and Digbeth in Birmingham; and Thornton Heath in London. Only the community in Digbeth had not experienced flooding in the past 30 years [46] and was used as a control group (of non-flooded community). London and Birmingham are the two largest cities in the UK, and they were selected because they contain communities with flooding experience. Communities in London, Birmingham, and Semarang represent communities in urban areas faced with a certain risk of flooding. This study does not suggest that either of these urban areas are more susceptible to flooding than other areas of Indonesia and the UK. However, they are deemed as representative of the comparative assessment of SR perceptions across flooded and non-flooded urban communities in the UK and Indonesia. Witton and Selly Park are urbanised areas close to water sources within tributaries of River Tame and River Rea. Both Witton and Selly Park often experience flooding, including major flooding in summer 2007. Flood defence schemes were implemented in Autumn 2016 [47]. The Thornton Heath community is in the London Borough of Croydon; it experienced flooding and faced a significant flooding risk from several sources, including sewer flooding from the Thames water, surface water flooding, groundwater flooding, and water run-off due to local topography of steep slopes in the vicinity areas of Coulsdon, Kenley, and Upper Norwood. Further details of UK case studies can be found in Soetanto et al. [16].

\section{Research Methods}

Quantitative research was adopted in this study. Data were collected via surveys targeting householders in Indonesian and UK communities using a questionnaire containing SR statements. The SR scale was originally developed by Berkowitz and Lutterman [48] to measure an individual's acceptance of traditional society values. As the aim of the questionnaire survey in the current study was to collate the perceptions of community groups in relation to flooding, the original questionnaire was extended and the attitudinal statements were modified and used to collect SR perceptions in UK communities [16]. Considering cultural and political sensitivities of the statements for the general public, two statements in Soetanto et al. [16] were excluded from the questionnaire for Indonesian communities. In total, ten SR statements were comparable across both Indonesian and UK communities. Table 2 lists the SR statements that were used in both Indonesian and UK questionnaire surveys, and their most relevant cultural dimensions. The SR statements were not created based on cultural dimensions. Instead, the dimensions were allocated to each SR statement as they were deemed most relevant. The statements were translated to Bahasa Indonesia. The questionnaire was pilot-tested by the research team and project partners [43]. The respondents were required to indicate their agreement against these statements on a 4-point scale ranging from 'Strongly Agree' (4) to 'Strongly Disagree' (1). In the analysis, several statements were reverse scored to counter acquiescence bias. For the comparative analysis, the averages of aggregated scores were used for each statement.

Whilst the questionnaires were distributed and collected by hand in the UK communities (see [16] for further details), the survey of Indonesian communities was conducted in person at each participant's home (see [43] for further details). This strategy was adopted to recognise the personal emphasis of conducting such surveys in Indonesian communities. This process allowed interpersonal interaction between survey participants and research assistants, clarification of the questionnaire as required, and ensured full questionnaire completion as well as a good response rate. Despite careful administration of the questionnaire in both countries, possible biases were due to non-probabilistic sampling of the respondents, and the presence of research assistants. Non-probabilistic sampling was considered in the interpretation of the findings [16]. The research assistants were trained to minimise biases and take a uniform and systematic approach in conducting the surveys. Table 3 depicts the number of completed questionnaires for each community in both countries. 
Table 2. Statements for SR questionnaires and most relevant cultural dimensions.

\begin{tabular}{|c|c|c|}
\hline No & Statement & Cultural Dimension \\
\hline 1 & $\begin{array}{l}\text { It is no use worrying about flooding within the } \\
\text { community as I can't do anything about it anyway. }\end{array}$ & UAI \\
\hline 2 & $\begin{array}{l}\text { Every person should give some of their time for the } \\
\text { good of their local community. }\end{array}$ & IDV \\
\hline 3 & $\begin{array}{l}\text { Letting your neighbours down is not so bad because } \\
\text { you can't do good all the time for everybody. }\end{array}$ & IDV \\
\hline 4 & $\begin{array}{l}\text { It is the duty of each member of a community to do } \\
\text { the very best they can to increase their protection } \\
\text { against floods. }\end{array}$ & IDV \\
\hline 5 & $\begin{array}{l}\text { People would be a lot better off if they could live far } \\
\text { away from other people and have less interaction } \\
\text { with each other. }\end{array}$ & IDV \\
\hline 6 & $\begin{array}{l}\text { I would like to take part in a community } \\
\text { volunteering project. }\end{array}$ & IDV \\
\hline 7 & $\begin{array}{l}\text { I feel very bad when I have failed to finish a job I } \\
\text { promised I would do. }\end{array}$ & IVR \\
\hline 8 & I feel it is important to always tell the truth to others. & IDV \\
\hline 9 & $\begin{array}{l}\text { I feel it is important to get on well with your } \\
\text { neighbours. }\end{array}$ & IDV \\
\hline 10 & $\begin{array}{l}\text { I do not feel that climate change is an important } \\
\text { issue that will affect me. }\end{array}$ & IDV \\
\hline
\end{tabular}

Table 3. Number of survey participants.

\begin{tabular}{|c|c|c|c|c|}
\hline Countries & Communities & $\begin{array}{l}\text { Flooded/Non- } \\
\text { Flooded }\end{array}$ & $\begin{array}{c}\text { No. of } \\
\text { Participants }\end{array}$ & $\begin{array}{l}\text { Total Participants in } \\
\text { Each Country }\end{array}$ \\
\hline \multirow[t]{3}{*}{ Indonesia } & Karangayu & Flooded & 60 & \multirow{3}{*}{180} \\
\hline & Trimulyo & Flooded & 60 & \\
\hline & Gunung Pati & Non-flooded & 60 & \\
\hline \multirow[t]{4}{*}{ UK } & Witton & Flooded & 81 & \multirow{4}{*}{313} \\
\hline & Selly Park & Flooded & 94 & \\
\hline & Digbeth & Non-flooded & 49 & \\
\hline & Thornton Heath & Flooded & 89 & \\
\hline
\end{tabular}

Data were analysed based on comparisons between the mean of SR scores and $t$-tests to confirm the statistical difference between two datasets. Five comparisons were conducted to obtain meaningful analyses that addressed the aim of this paper. They were comparisons between means of SR scores of aggregated responses of (i) Indonesian and UK communities; (ii) flooded and non-flooded communities in the UK; (iii) flooded and non-flooded communities in Indonesia; (iv) Indonesian and UK flooded communities; and (v) Indonesian and UK non-flooded communities. These comparisons allowed the relative influence of socio-cultural factors and flooding experience on SR scores to be assessed. The statistical (null) hypotheses were as follows: (i) there is no difference in SR perceptions between communities in Indonesia and the UK, and (ii) there is no difference in SR perceptions between flooded and non-flooded communities.

\section{Results}

The resultant profiles of the comparisons of mean SR score are presented in Figures 4-8 with means of SR score and statistical test results for each statement, provided in Tables 4 and 5 , respectively. For the purpose of countering acquiescence bias, Statements 1, 3, 5, and 10 
were reverse scored so that their SR scores were aligned with the definition of SR and follow the same direction as the other statements.

Table 4. Means of aggregated SR scores.

\begin{tabular}{ccccccc}
\hline \multirow{3}{*}{ Statement } & \multicolumn{2}{c}{ Indonesia } & & & UK \\
\cline { 2 - 6 } & Flooded & $\begin{array}{c}\text { Non- } \\
\text { Flooded }\end{array}$ & All & Flooded & $\begin{array}{c}\text { Non- } \\
\text { Flooded }\end{array}$ & All \\
\hline 1 & 2.79 & 2.34 & 2.65 & 2.86 & 2.29 & 2.77 \\
2 & 3.12 & 3.24 & 3.16 & 2.77 & 2.24 & 2.68 \\
3 & 3.03 & 3.05 & 3.04 & 2.34 & 2.20 & 2.32 \\
4 & 2.97 & 3.07 & 3.00 & 2.83 & 2.18 & 2.73 \\
5 & 3.29 & 3.43 & 3.34 & 2.97 & 2.69 & 2.92 \\
6 & 2.92 & 2.91 & 2.92 & 2.98 & 2.31 & 2.88 \\
7 & 2.89 & 3.02 & 2.93 & 3.00 & 2.65 & 2.95 \\
8 & 3.13 & 3.28 & 3.17 & 2.99 & 2.27 & 2.88 \\
9 & 3.40 & 3.48 & 3.43 & 2.97 & 2.78 & 2.94 \\
10 & 3.01 & 2.97 & 2.99 & 2.42 & 2.22 & 2.39 \\
\hline
\end{tabular}

Table 5. Results of $t$-tests for comparing SR perceptions.

\begin{tabular}{|c|c|c|c|c|c|}
\hline Statement & $\begin{array}{c}\text { Indonesia } \\
\text { vs. } \\
\text { the UK } \\
\text { (Figure 4) }\end{array}$ & $\begin{array}{l}\text { UK Flooded } \\
\text { vs. } \\
\text { UK } \\
\text { Non-Flooded } \\
\text { (Figure 5) }\end{array}$ & $\begin{array}{c}\text { Indonesia } \\
\text { Flooded vs. } \\
\text { Indonesia } \\
\text { Non-Flooded } \\
\text { (Figure 6) }\end{array}$ & $\begin{array}{c}\text { Indonesia } \\
\text { Flooded vs. UK } \\
\text { Flooded } \\
\text { (Figure 7) }\end{array}$ & $\begin{array}{c}\text { Indonesia } \\
\text { Non-Flooded vs. } \\
\text { UK Non-Flooded } \\
\text { (Figure 8) }\end{array}$ \\
\hline 1 & 0.083 & $<0.001 * *$ & $<0.001 * *$ & 0.362 & 0.690 \\
\hline 2 & $<0.001 * *$ & $<0.001 * *$ & 0.099 & $<0.001 * *$ & $<0.001^{* *}$ \\
\hline 3 & $<0.001 * *$ & 0.132 & 0.854 & $<0.001 * *$ & $<0.001^{* *}$ \\
\hline 4 & $<0.001^{* *}$ & $<0.001 * *$ & 0.069 & $0.019 *$ & $<0.001 * *$ \\
\hline 5 & $<0.001 * *$ & $0.004 * *$ & 0.107 & $<0.001 * *$ & $<0.001 * *$ \\
\hline 6 & 0.428 & $<0.001^{* *}$ & 0.972 & 0.195 & $<0.001 * *$ \\
\hline 7 & 0.699 & $<0.001^{* *}$ & $0.045 *$ & 0.029 * & $<0.001^{* *}$ \\
\hline 8 & $<0.001^{* *}$ & $<0.001^{* *}$ & 0.049 * & $0.015^{*}$ & $<0.001 * *$ \\
\hline 9 & $<0.001 * *$ & $0.005 * *$ & 0.298 & $<0.001 * *$ & $<0.001 * *$ \\
\hline 10 & $<0.001 * *$ & 0.037 * & 0.626 & $<0.001 * *$ & $<0.001 * *$ \\
\hline
\end{tabular}

Figure 4 depicts a profile of mean SR scores compared between the aggregated responses of Indonesian and UK communities. It appears that SR scores of Indonesian communities are higher (significant at $1 \%$ level) in most statements with the exception of Statements 1, 6, and 7. The comparison of SR scores for Statement 1 seems to be consistent with the UAI score comparison between Indonesia and the UK from Hofstede Insights in Figure 1 [35] in that Indonesian communities tend to have higher UAI, reflected in a lower SR score for that statement (although it is not significant). No significant differences were observed between SR scores from Indonesian and UK communities in Statements 6 and 7. In the case of most statements $(2,3,4,5,8,9$, and 10), the significantly higher SR scores relevant to the IDV dimension indicate that Indonesian communities demonstrate a tendency to place greater importance on their association to their communities rather than UK communities do. 


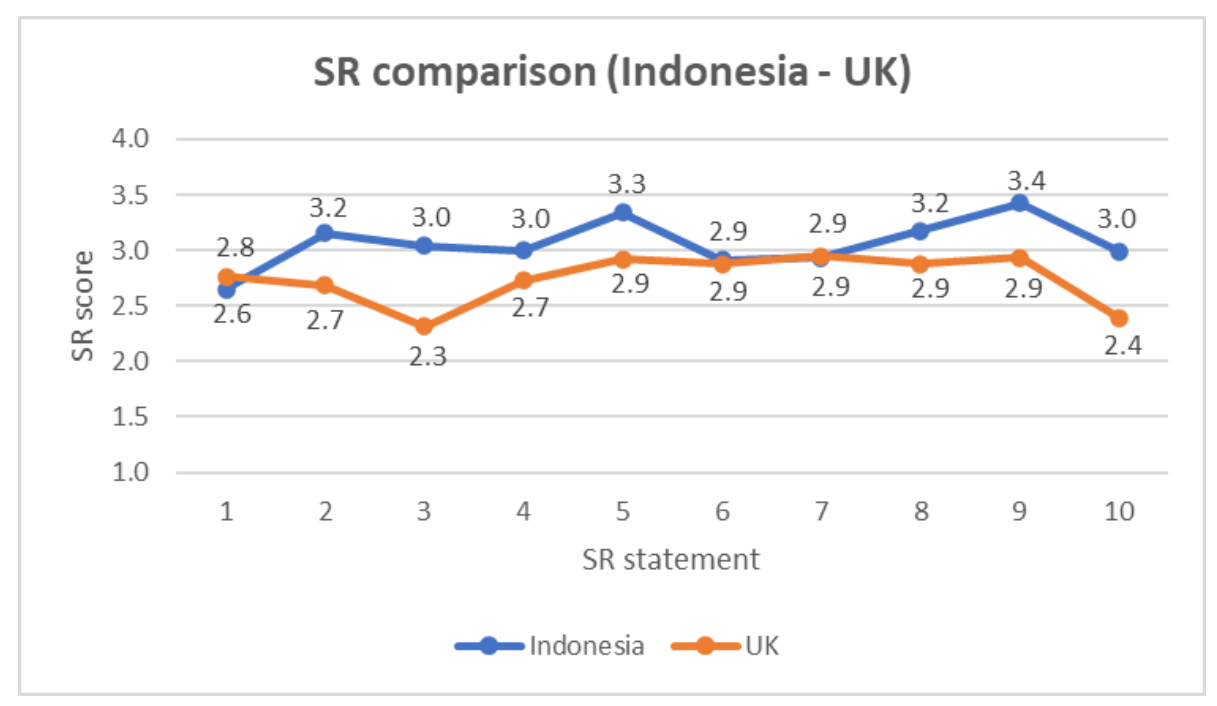

Figure 4. Comparison of SR scores between Indonesian and UK communities.

Figure 5 shows a profile of mean SR score comparisons between aggregated responses of flooded and non-flooded communities in the UK. Statistical test results presented in Table 5 suggest that the differences of SR scores are significant in all statements but Statement 3. The significant difference of SR scores regarding Statements 1 and 10 suggests that UK flooded communities are much more concerned about flooding and climate change than non-flooded communities. Based on a national survey in the UK, Spence et al. [49] found that individuals with experience of flooding expressed more concern on climate change and willingness to take action. Significant differences of SR scores for Statements $2,4,5,6$, and 9 suggest that flooded communities recognise the role of community more strongly than non-flooded communities do. Similarly, Statements 7 and 8 suggest that flooded communities have a greater tendency to take care of their responsibility to others than non-flooded communities. The results in Figure 5 highlight the critical role of flooding experience on elevating the importance of community, shaping the perception of flooding, and acting on climate change. Previous studies indicate that experience of flooding is an important factor influencing risk awareness, response, and preparedness (e.g., $[27,50,51])$, which, in turn, can impact on the perceptions of SR.

Figure 6 demonstrates a profile of mean SR score comparisons between aggregated responses of flooded and non-flooded communities in Indonesia. There were no significant differences of aggregated SR scores between flooded and non-flooded communities in all statements with the exception of Statements 1, 7, and 8. The significant difference of SR scores for Statement 1 suggests that Indonesian flooded communities are much more concerned about flooding than non-flooded communities. Some evidence of significant differences in Statements 7 and 8 may be due to socio-economic status of the respondents in more affluent, non-flooded area (in Gunung Pati), where the respondents have more permanent jobs and incomes (see 'professions' in Table 1). Overall, the findings suggest that the impact of flooding experience on the level of SR responses is minimum, and much less than the impact on SR responses from UK communities. One may speculate that this lesser impact of flooding experience may be due the stronger tendency of a more collective culture within Indonesian communities (as opposed to a more individualistic culture in the UK). This argument aligns with findings from Taylor and Peace [26] that, in Indonesian communities, the traditional practice of 'gotong royong', reinforced by religious beliefs encourages people who do not live in flooded areas to help flooded communities. Arguably, this elevates SR scores of those participants from non-flooded communities. This suggests that the impact of flooding experience is overridden by the dominant collective culture of Indonesian communities. 


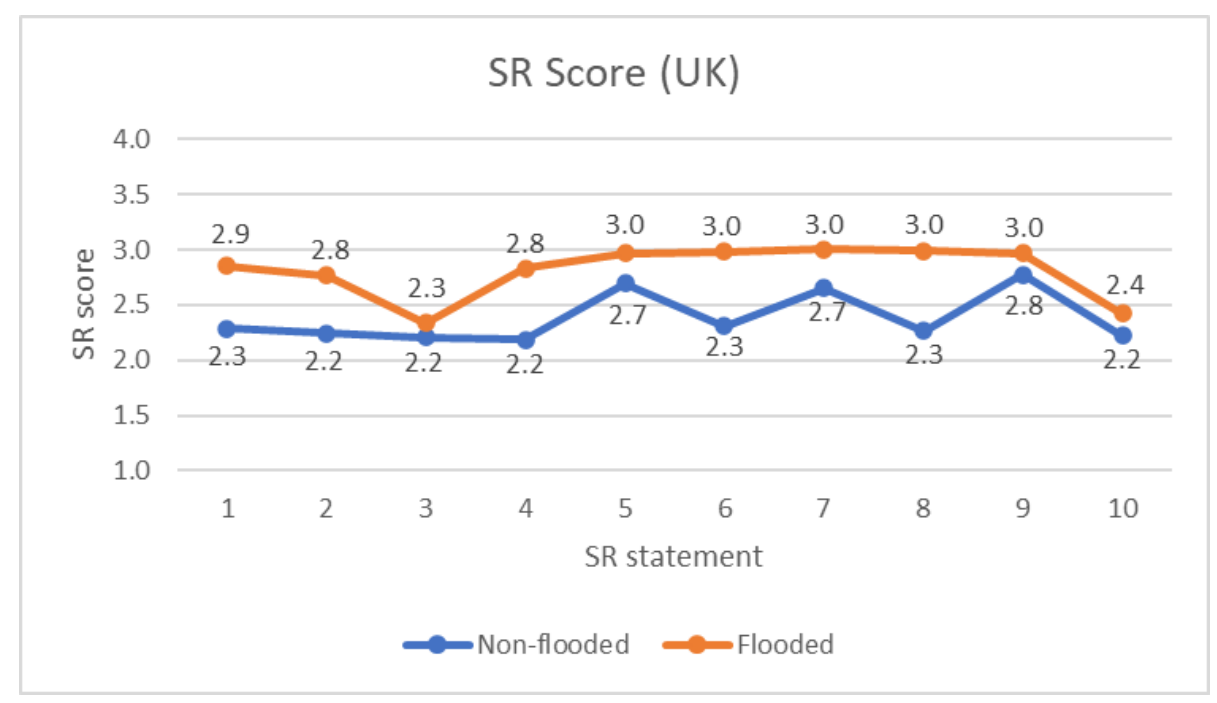

Figure 5. Comparison of SR scores between flooded and non-flooded communities in the UK.

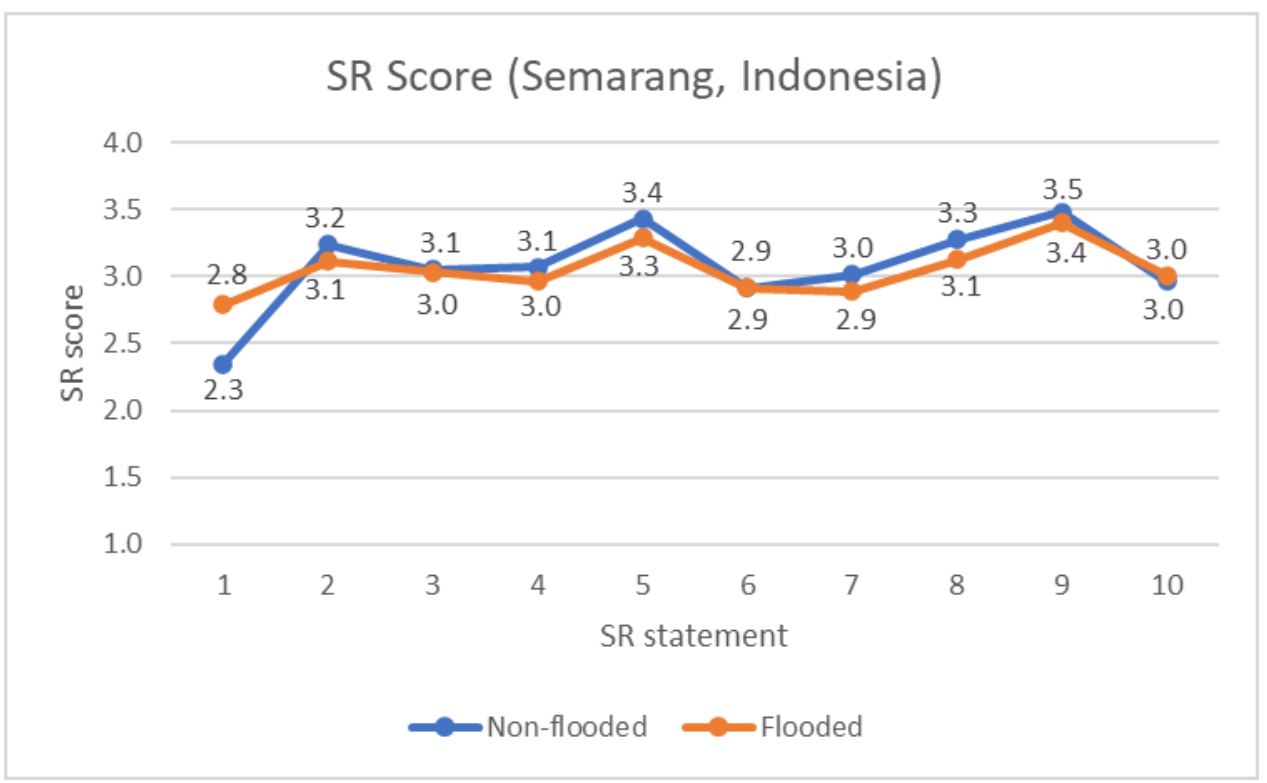

Figure 6. Comparison of SR scores between flooded and non-flooded communities in Indonesia.

Figure 7 depicts a profile of mean SR score comparisons between aggregated responses of Indonesian and UK flooded communities. Aggregated SR scores from Indonesian communities are significantly higher than those from UK communities in most statements, except for Statements 6 and 7. The reason that UK communities have higher SR scores regarding Statement 6 (although not significant) may be due to the more commonly publicised 'formal' volunteering activities in the UK. In Indonesia, volunteering is often seen as an 'informal' activity, which is an inherent part of being a member of a close-knit community. Hence, participation is achieved via word of mouth, and an expectation that each community member will raise to the occasion rather than a more 'formal' sense of 'volunteering'. The traditional practice of 'gotong royong' encourages a strong volunteering culture [26]. In relation to Statement 7, one possible reason why Indonesian communities had significantly lower aggregated SR scores than UK communities is the generally low socio-economic status of Indonesian flooded communities surveyed with members who usually hold casual jobs and have an inherently low sense of achievement. Overall, the findings associated with Figure 7 reinforce the argument presented previously that the SR scores of UK communities are generally lower than those of Indonesian communities, even 
in the case in which both Indonesian and UK flooded communities' SR scores are compared. This supports findings of previous studies regarding the role of inherent socio-cultural influences, such as the collective culture of Indonesian communities.

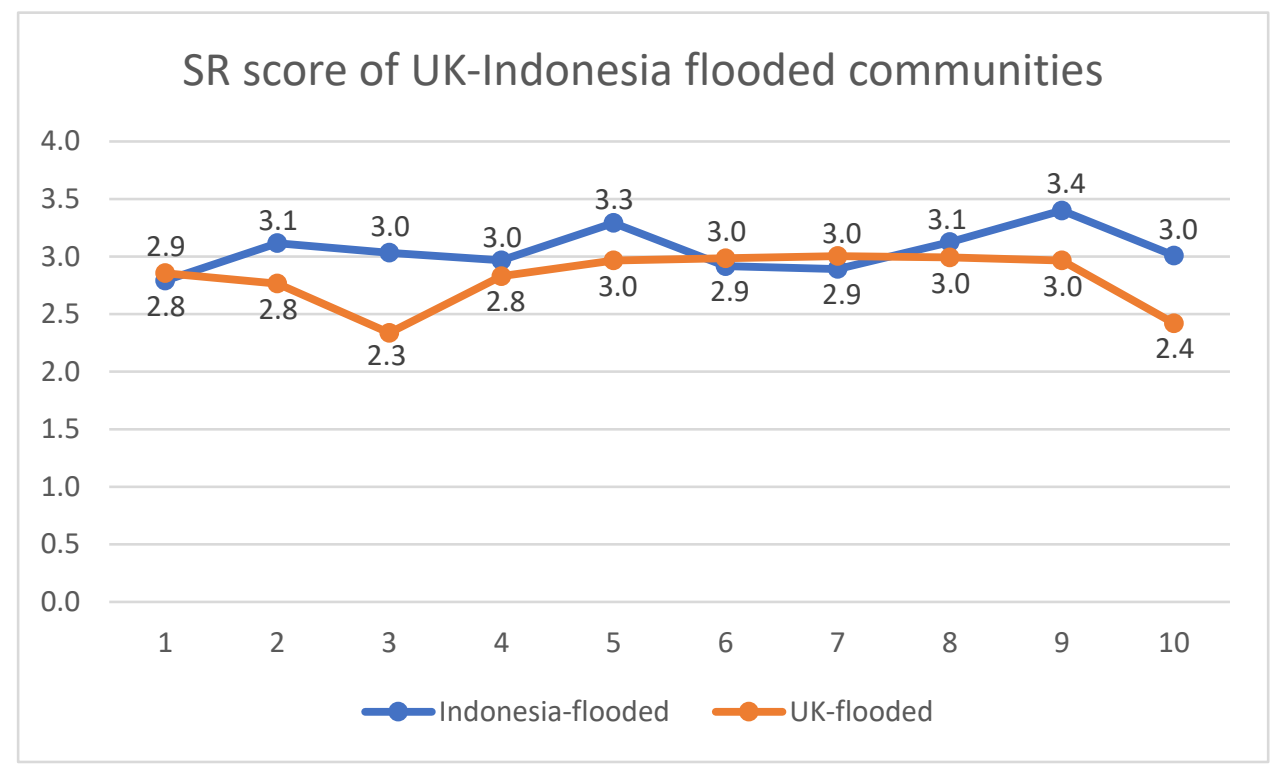

Figure 7. Comparison of SR scores between Indonesian and UK flooded communities.

Figure 8 shows a profile of mean SR score comparisons between aggregated responses of Indonesian and UK non-flooded communities. In all, except Statement 1, Indonesian non-flooded communities exhibit significantly higher SR scores than UK non-flooded communities. An examination of the profile shows wider SR score gaps between these two communities. Further scrutiny of profiles shown in Figures 7 and 8 in tandem suggests experience of flooding results in higher SR scores for UK communities although not as high as the SR scores of Indonesian communities. Thus, it is reasonable to conclude that experience of flooding may impact SR perception at different levels across communities globally, highlighting the more pronounced influence of socio-cultural factors on SR perception in collectivistic societies.

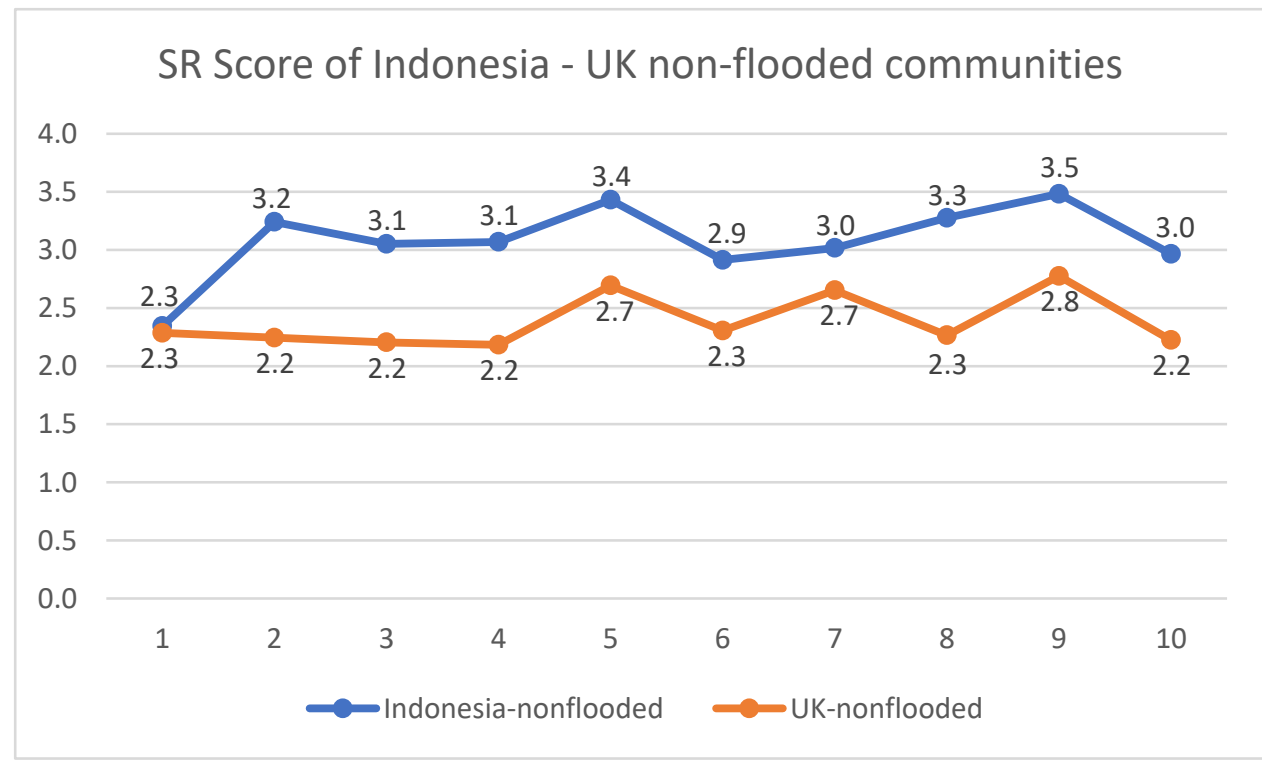

Figure 8. Comparison of SR scores between Indonesian and UK non-flooded communities. 


\section{Discussion and Conclusions}

Community resilience is a dynamic and multi-faceted phenomenon that determines the ability of a community to withstand the impact of a disaster and carry-on functioning its aftermath. Community resilience is largely determined by the collective actions of community members to work together to improve the resilience of themselves and the community. This requires each member of the community to exercise personal responsibility to take resilience-enhancing measures. However, the extant literature suggests that the take up of resilience-enhancing measures that improve preparedness is generally low across various natural hazards [8-12]. Furthermore, the responsibility for improving resilience is less clear [7]. Scholars attempted to identify factors that influence preparedness to natural hazards (e.g., [13,19-23]). In this paper, the perception of Social Responsibility (SR) is defined as an individual's responsibility and willingness to contribute to collective actions that enhance the resilience of the community they are part of. Thus, it is argued to be one of the antecedents influencing an individual's willingness to undertake resilience-enhancing measures that can significantly contribute to community resilience through individual and collective actions.

Responsibility-related concepts (personal responsibility, responsibility for preparing/dealing with hazards, responsibility for others, and SR) have been identified as important factors influencing preparedness to natural hazards [12,13]. However, their specific impact on preparedness has not been empirically ascertained. Soetanto et al. $[15,16]$ identified the role of 'ethnicity' of individuals with different underlying socio-cultural backgrounds, arguably determining their SR perceptions. Soetanto et al. [16] further found that experience of flooding was the stronger predictor of SR scores. The literature suggests that an individual's experience of flooding can influence their awareness of risk, response, and preparedness (e.g., $[27,50,51]$ ), which in turn suggests that they may show higher perceptions of SR than people who have not experienced flooding. This finding calls for an investigation to ascertain the role of socio-cultural factors and the experience of flooding in determining the level of SR in different cultural contexts.

Communities in three large cities in Indonesia and the UK, two countries with different socio-cultural backgrounds, participated in questionnaire surveys to obtain their SR perceptions. The results suggest that generally, Indonesian communities demonstrate a higher level of SR scores than UK communities. A comparison of SR scores between flooded and non-flooded communities in the UK shows higher levels of SR in flooded communities, whereas the same comparison in Indonesian communities indicates almost similar levels of SR. A comparison of SR scores between Indonesian and UK flooded communities shows a higher level of SR in Indonesian communities in several measures. Further comparison of SR scores between Indonesian and UK non-flooded communities demonstrates higher SR in Indonesian communities in all but one measure. This suggests that experience of flooding has a much stronger influence on raising SR perceptions in UK communities. Socio-cultural backgrounds may explain these differences in SR perceptions, particularly in relation to a collectivist orientation and the close-knit nature of Indonesian communities. Although higher SR perceptions do not necessarily mean higher level of preparedness actions, this finding has highlighted the critical influence of socio-cultural context on endeavours to enhance community resilience that relies on collective actions by individuals.

In a study of SR perceptions across ethnic groups in the UK, Mullins and Soetanto [15] found that individuals from Asian ethnic groups in Birmingham and London communities reported significantly higher levels of SR than those from the white and black ethnic groups, despite a limited sample of non-white participants. The respondents in Asian ethnic groups originated from South Asia regions. It is likely that they were the first generation of older people with South Asian backgrounds in the UK who may have experienced severe flooding in their home countries [16]. However, as the questionnaires were distributed to communities regardless of their ethnic background and origin, this explanation cannot be determined [16]. The finding in this paper provides new evidence across the two countries with contrasting cultural backgrounds. It reinforces the initial finding that individuals 
from (or with origin from) East Asia regions have a higher level of SR than those from Western countries.

\section{Practical and Policy Implications}

The findings of this paper have two practical and policy implications. Firstly, sociocultural context (e.g., social networks) provides means for interpreting risks and actions, as well as developing mitigation strategies [23]. Therefore, social and cultural factors need to be considered in the formulation of risk communication strategies targeted to specific community groups. Due to their collectivistic orientation, community groups in Indonesia prefer to live in close interaction within their neighbourhood and have personal attachment to place $[25,52]$. Thus, in Indonesia, the use of community groups, such as Kelurahan Siaga Bencana (KSB or Disaster Preparedness Group) in Semarang communities [37], could be effectively used to promote preparedness actions. The role of community (KSB) leaders is important in encouraging individual and collective actions within Indonesian communities, characterised by high Power Distance (PD) and Uncertainty Avoidance (UAI), either through automatic compliance (of tendency in high PD society) or the adoption preparedness measures to avoid uncertainty (in society with high UA) [23]. In UK communities, risk communication strategies need to be tailored to consider multi-cultural and multi-ethnic groups within each community. Thus, a one-strategy approach does not fit all because different groups may respond differently to the same information about the threat of natural hazards.

Secondly, this finding highlights important considerations for a cross-cultural learning for improving preparedness (e.g., [18]). As discussed previously, Hu et al. [34] identified the two drivers of collective action: individual motivation and social connectivity. In collectivistic communities, strategies to enhance collective action could be designed to heighten an individual's motivation to take initiative that promotes collective actions, instils confidence in the efficacy of their individual actions, and contributes to improving community resilience. On the other hand, social events that promote a community's cohesion, such as those demonstrated in the Indonesian neighbourhoods, should also be considered in individualistic communities. Such an approach would facilitate a transition from relational community to locational community, as suggested to take place in communities in New Zealand and Japan [22]. The findings also highlight the need to emphasise the alignment between strategies to improve preparedness and the socio-cultural context of the targeted communities.

\section{Future Research}

This work identified the influence of socio-cultural factors on the perceptions of $\mathrm{SR}$, which is considered one of the key variables that determine collective action and preparedness against natural hazards. Due to widespread flooding risk globally, it is proposed that the applicability of this finding and the extension of this SR concept are tested across different communities with different socio-cultural backgrounds. Currently, few cross-cultural studies have been conducted to investigate preparedness, let alone SR perceptions. The finding that the experience of flooding exerts a different influence on SR perceptions in two countries raises an important question regarding the extent by which this influence translates in the adoption of resilience-enhancing measures and the mediating role of socio-cultural factors. Further research is needed to validate the findings presented in this paper.

Author Contributions: Conceptualization, R.S.; Data curation, N.D.; Formal analysis, R.S.; Funding acquisition, R.S. and J.U.D.H.; Investigation, F.H., N.D. and L.B.; Methodology, R.S.; Project administration, F.H., N.D. and J.U.D.H.; Resources, R.S., J.U.D.H. and F.H.; Supervision, R.S., L.B. and J.U.D.H.; Writing—original draft, R.S.; Writing—review \& editing, L.B. and N.D. All authors have read and agreed to the published version of the manuscript. 
Funding: This research was funded by the Engineering and Physical Science Research Council (EPSRC Reference: EP/F035861/1) and Newton Institutional Links/INSINAS-KLN scheme (jointly funded by the British Council and Ministry of Research, Technology and Higher Education of the Republic of Indonesia, grant reference: GA261682033; 397-05/UN7.5.1/PG/2017; 10159/UN7.P4.3/PP/2018).

Data Availability Statement: The data are not publicly available due to confidentiality of the study participants.

Acknowledgments: The author gratefully acknowledge the funding from the Engineering and Physical Science Research Council (EPSRC, UK), Newton Fund (UK), and MenRisTekDikti (Indonesia). The authors wish to thank Aaron Mullins, who collected data from the UK communities, all participants of the survey in Indonesia and the UK, and Yansen Lautama Soni, who proofread the first version of the paper.

Conflicts of Interest: The authors declare no conflict of interest.

\section{References}

1. Fan, Y.; Lyu, X. Exploring two decades of research in community resilience: A content analysis across the international literature. Psychol. Res. Behav. Manag. 2021, 14, 1643-1654. [CrossRef]

2. Cheetham, M.; Mallet, T.; Chastel, E.; Tourment, R.; Robustelli, P.; Pelt, P. Building a resilient system of defence against flooding from the Rhône. Proc. Inst. Civ. Eng. Water Manag. 2015, 168, 74-84. [CrossRef]

3. Odemerho, F. Building climate change resilience through bottom-up adaptation to flood risk in Warri, Nigeria. Environ. Urban. 2014, 27, 139-160. [CrossRef]

4. Osti, R.P. Embedding Community-Based Flood Risk Management in Investment: A Part-to-Whole Approach; East Asia Working Paper Series No.12; Asian Development Bank: Metro Manila, Philippines, 2017.

5. Dittrich, R.; Wreford, A.; Butler, A.; Moran, D. The impact of flood action groups on the uptake of flood management measures. Clim. Chang. 2016, 138, 471-489. [CrossRef]

6. Thistlethwaite, J.; Henstra, D.; Brown, C.; Scott, D. Barriers to Insurance as a Flood Risk Management Tool: Evidence from a Survey of Property Owners. Int. J. Disaster Risk Sci. 2020, 11, 263-273. [CrossRef]

7. Joseph, R.; Proverbs, D.; Lamond, J. Homeowners' perceptions of property-level flood risk adaptation (PLFRA) measures: The case of the summer 2007 flood event in England. Int. J. Saf. Secur. Eng. 2015, 5, 251-265. [CrossRef]

8. Krasovskaia, I. Perception of Flood Hazard in Countries of the North Sea Region of Europe; Norwegian Water Resources and Energy Directorate: Oslo, Norway, 2005.

9. Terpstra, T.; Gutteling, J.M. Households' Perceived Responsibilities in Flood Risk Management in The Netherlands. Int. J. Water Resour. Dev. 2008, 24, 555-565. [CrossRef]

10. Kievik, M.; Gutteling, J.M. Yes, we can: Motivate Dutch citizens to engage in self-protective behaviour with regard to flood risks. Nat. Hazards 2011, 59, 1475-1490. [CrossRef]

11. Paton, D.; Jang, L.J.; Kitagawa, K.; Mamula-Seadon, L.; Sun, Y. Coping with adapting to natural hazard consequences: Crosscultural perspective. In Disaster Resilience: An Integrated Approach, 2nd ed.; Paton, D., Johnston, D., Eds.; Charles C Thomas: Springfield, IL, USA, 2017.

12. Paton, D. Disaster risk reduction: Psychological perspectives on preparedness. Aust. J. Psychol. 2019, 71, 327-341. [CrossRef]

13. Becker, J.; Paton, D.; Johnston, D.; Ronan, K. Societal influences on earthquake information meaning-making and household preparedness. Int. J. Mass Emerg. Disasters 2014, 32, 317-352.

14. ISO 26000; Guidance on Social Responsibility; International Standard Organization: Geneva, Switzerland, 2010.

15. Mullins, A.; Soetanto, R. Ethnic differences in perceptions of social responsibility: Informing risk communication strategies for enhancing community resilience to flooding. Disaster Prev. Manag. 2013, 22, 119-131. [CrossRef]

16. Soetanto, R.; Mullins, A.; Achour, N. The perceptions of social responsibility for community resilience to flooding: The impact of past experience, age, gender and ethnicity. Nat. Hazards 2017, 86, 1105-1126. [CrossRef]

17. Blumer, H. Symbolic Interactionism: Perspective and Method; Prentice-Hall: Englewood Cliffs, NJ, USA, 1969.

18. Paton, D.; Sagala, S.; Okada, N.; Jang, L.-J.; Bürgelt, P.T.; Gregg, C.E. Making sense of natural hazard mitigation: Personal, social and cultural influences. Environ. Hazards 2010, 9, 183-196. [CrossRef]

19. Bubeck, P.; Botzen, W.; Aerts, J.C.J.H. A Review of Risk Perceptions and Other Factors that Influence Flood Mitigation Behavior. Risk Anal. 2012, 32, 1481-1495. [CrossRef]

20. Lindell, M.K.; Perry, R.W. The Protective Action Decision Model: Theoretical Modifications and Additional Evidence. Risk Anal. 2011, 32, 616-632. [CrossRef]

21. Scovell, M.; McShane, C.; Swinbourne, A.; Smith, D. Rethinking Risk Perception and its Importance for Explaining Natural Hazard Preparedness Behavior. Risk Anal. 2021. [CrossRef]

22. Paton, D.; Bajek, R.; Okada, N.; McIvor, D. Predicting community earthquake preparedness: A cross-cultural comparison of Japan and New Zealand. Nat. Hazards 2010, 54, 765-781. [CrossRef] 
23. Paton, D.; Okada, N.; Sagala, S. Understanding Preparedness for Natural Hazards: Cross cultural comparison. IDRiM J. 2013, 3 , 18-35. [CrossRef]

24. Lavigne, F.; De Coster, B.; Juvin, N.; Flohic, F.; Gaillard, J.C.; Texier, P.; Morin, J.; Sartohadi, J. People's behaviour in the face of volcanic hazards: Perspectives from Javanese communities, Indonesia. J. Volcanol. Geotherm. Res. 2008, 172, 273-287. [CrossRef]

25. Hellman, J. Living with floods and coping with vulnerability. Disaster Prev. Manag. Int. J. 2015, 24, 468-483. [CrossRef]

26. Taylor, H.; Peace, R. Children and cultural influences in a natural disaster: Flood response in Surakarta, Indonesia. Int. J. Disaster Risk Reduct. 2015, 13, 76-84. [CrossRef]

27. Sattler, D.N.; Kaiser, C.F.; Hittner, J.B. Disaster Preparedness: Relationships Among Prior Experience, Personal Characteristics, and Distress. J. Appl. Soc. Psychol. 2000, 30, 1396-1420. [CrossRef]

28. Hofstede, G. Culture's Consequences: International Differences in Work-Related Values; Sage Publications: Beverly Hills, CA, USA, 1980.

29. Hofstede, G.; Hofstede, G.J.; Minkov, M. Cultures and Organizations: Software of the Mind, 3rd ed.; McGraw-Hill: New York, NY, USA, 2010.

30. Brettel, M.; Engelen, A.; Heinemann, F.; Vadhanasindhu, P. Antecedents of Market Orientation: A Cross-Cultural Comparison. J. Int. Mark. 2008, 16, 84-119. [CrossRef]

31. Collins, N.; Chou, Y.-M.; Warner, M.; Rowley, C. Human factors in East Asian virtual teamwork: A comparative study of Indonesia, Taiwan and Vietnam. Int. J. Hum. Resour. Manag. 2015, 28, 1475-1498. [CrossRef]

32. Chwialkowska, A.; Bhatti, W.A.; Glowik, M. The influence of cultural values on pro-environmental behavior. J. Clean. Prod. 2020, 268, 122305. [CrossRef]

33. Setiawan, A. The Influence of Social Context on Co-Design Practice between Indonesia and the UK. Ph.D. Thesis, Lancaster University, Lancashire, UK, 2021.

34. Hu, H.-H.; Lin, J.; Cui, W. Cultural differences and collective action: A social network perspective. Complexity 2015, $20,68-77$. [CrossRef]

35. Hofstede Insights. Available online: https://www.hofstede-insights.com/ (accessed on 1 December 2021).

36. Basu-Zharku, I.O. Effects of collectivistic and individualistic cultures on imagination inflation in Eastern and Western cultures. Inq. J. Stud. Pulse 2011, 3, 1-2. Available online: http:/ / www.inquiriesjournal.com/articles/1679/effects-of-collectivistic-andindividualistic-cultures-on-imagination-inflation-in-eastern-and-western-cultures (accessed on 27 December 2021).

37. Semarang City Government. Resilient Semarang: Moving Together towards a Resilient Semarang; Resilient Semarang Strategy Book, Initiated by 100 Resilient Cities; Semarang City Government: Semarang, Indonesia, 2016.

38. Marfai, M.A.; King, L.; Sartohadi, J.; Sudrajat, S.; Budiani, S.R.; Yulianto, F. The impact of tidal flooding on a coastal community in Semarang, Indonesia. Environmentalist 2008, 28, 237-248. [CrossRef]

39. BPBD Semarang. Available online: https://bpbd.semarangkota.go.id/ (accessed on 2 September 2019).

40. Rosa, A. Kota Semarang Dikepung Banjir, Ini Daerah Terdampak Paling Parah. Sindonews.com. 7 February 2021. Available online: https: / / daerah.sindonews.com/read/327082/707/kota-semarang-dikepung-banjir-ini-daerah-terdampak-paling-parah1612634547 (accessed on 27 December 2021).

41. Alfian, M.F. Banjir Kota Semarang Tersebar Di 10 Kecamatan. Halosemarang.id. 6 February 2021. Available online: https: / / halosemarang.id/banjir-kota-semarang-tersebar-di-10-kecamatan (accessed on 27 December 2021).

42. Suripin; Pujiastuti, R.; Widjonarko. The Initial Step for Developing Sustainable Urban Drainage System in Semarang CityIndonesia. Procedia Eng. 2017, 171, 1486-1494. [CrossRef]

43. Drosou, N.; Soetanto, R.; Hermawan, F.; Chmutina, K.; Bosher, L.; Hatmoko, J.U.D. Key Factors Influencing Wider Adoption of Blue-Green Infrastructure in Developing Cities. Water 2019, 11, 1234. [CrossRef]

44. OpenStreetMap ${ }^{\circledR}$ Is Open Data, Licensed under the Open Data Commons Open Database License (ODbL) by the OpenStreetMap Foundation (OSMF). Available online: www.openstreetmap.org (accessed on 30 January 2021). Copyright Page Available Online: https: / / www.openstreetmap.org/copyright (accessed on 30 January 2022).

45. Central Bureau of Statistics. Jawa Tengah Dalam Angka Tahun 2017/Central Java in Figures Year 2017; CBS: Semarang, Indonesia, 2017.

46. Mullins, A. Perception of Social Responsibility for Community Resilience to Extreme Flooding. Ph.D. Thesis, Coventry University, England, UK, 2012.

47. Rea Catchment Partnership, Planning Applications Submitted-Two Flood Alleviation Schemes in the Rea Catchment. Available online: http:/ / www.reacatchmentpartnership.co.uk/latest-news/item/67-planning-applications (accessed on 23 September 2016).

48. Berkowitz, L.; Lutterman, K.G. The Traditional Socially Responsible Personality. Public Opin. Q. 1968, 32, 169-185. [CrossRef]

49. Spence, A.; Poortinga, W.; Butler, C.; Pidgeon, N.F. Perceptions of climate change and willingness to save energy related to flood experience. Nat. Clim. Chang. 2011, 1, 46-49. [CrossRef]

50. Nicholson-Cole, S.A. Representing climate change futures: A critique on the use of images for visual communication. Comput. Environ. Urban Syst. 2005, 29, 255-273. [CrossRef]

51. Tapsell, S.; McCarthy, S.; Faulkner, H.; Alexander, M. Social Vulnerability to Natural Hazards. CapHaz-Net WP4 Report; Flood Hazard Research Centre, Middlesex University: England, UK, 2010. Available online: http:/ / caphaz-net.org/outcomes-results/CapHazNet_WP4_Social-Vulnerability2.pdf (accessed on 14 December 2015).

52. Daryanto, A.; Song, Z. A meta-analysis of the relationship between place attachment and pro-environmental behaviour. J. Bus. Res. 2021, 123, 208-219. [CrossRef] 